\title{
Az aktív ernyő anyagának szerepe a plazmanitridálás során
}

\section{The role of the material of active screen during the plasma nitriding process}

\author{
Kovács Dorina, ${ }^{1}$ Szabó Annamária, ${ }^{2}$ Kemény Alexandra ${ }^{3}$ \\ Budapesti Müszaki és Gazdaságtudományi Egyetem, Gépészmérnöki Kar, Anyagtudomány és Technológia \\ Tanszék, Budapest, Magyarország \\ ${ }^{1}$ dorina@eik.bme.hu \\ 2 annamaria.szabo97@gmail.com \\ 3alexa@eik.bme.hu
}

\begin{abstract}
In this research the effect of the active screen's material was investigated. 42CrMo4 steel was plasma nitrided with unalloyed steel, titanium and nickel active screen at 490 and $510{ }^{\circ} \mathrm{C}$ for $4 \mathrm{~h}$ in $75 \% \mathrm{~N}_{2}+25 \% \mathrm{H}_{2}$ gas mixture. Scanning electron microscopy (SEM), energy dispersive spectrometry (EDS) and X-ray photoelectron spectroscopy (XPS) were used for the characterisation of the surface properties. Iron-nitride was not formed on the surface with nickel screen. The evaluation of examination results showed that most of the detected nitrogen was molecular (N2) in the formed layer.
\end{abstract}

Keywords: active screen plasma nitriding, $X$-ray photoelectron spectroscopy.

\section{Összefoglalás}

A kutatás során az aktív ernyő anyagának szerepét vizsgáltuk plazmanitridálás során. 42CrMo4 típusú acélt nitridáltunk ötvözetlen acélból és titánból készített, valamint nikkelbevonatos aktív ernyővel. A plazmanitridálás 490 és $510{ }^{\circ} \mathrm{C}$-on, 4 órán keresztül $75 \% \mathrm{~N}_{2}+25 \% \mathrm{H}_{2}$ gázkeverékkel történt. A vizsgálatokhoz pásztázó elektronmikroszkópot, energiadiszperzív röntgenspektrometriát és röntgenfotoelektron-spektrometriát alkalmaztunk. A vizsgálatok kimutatták, hogy a nikkelbevonatos ernyővel vas-nitrid nem képződött a felületen, továbbá a nitrogén többnyire molekuláris (N2) formában van jelen a képződött rétegben.

Kulcsszavak: aktív ernyős plazmanitridálás, röntgenfotoelektron-spektrometria.

\section{Bevezetés}

A nitridálás egy olyan termokémiai felületkezelési eljárás, mely során a nitrogénnek a felületbe diffundáltatásával és a jelen lévő atomokkal alkotott nitridfázisok létrehozatalával kemény, kopásálló réteg hozható létre. A nitrogén intersztíciós ötvözőként oldódik a vas szilárd oldataiban, valamint képes reakcióba lépni és vegyületet alkotni az acél egyes ötvözőivel, alkotóelemeivel [1, 2]. A hőmérséklet növelésével fokozódik az acélban található vasatomok rezgőmozgása, ami lehetővé teszi a nitrogénatomoknak a vas kristályrácsába történő bediffundálását. A szilárd oldat telítése után a nitrogén képes a vas atomjaival vegyületet is alkotni, mellyel az alkatrész felületén összefüggő, a szilárd oldatban oldott nitrogén hatásához képest nagyobb keménységű réteget alkot [3, 4].

A plazmanitridálást, más néven ionnitridálást, az 1920-as években vezették be mint felületkezelési eljárást. Amint a gáz ionizációja megkezdődik, az ionok bombázzák a munkadarab felületét. Ezt a jelenséget porlasztásnak is nevezik, azért, 
mert az ionok becsapódása a fémfelületről le tudja szakítani az ott megtapadt felületi szennyeződés anyagának atomjait és a fématomokat is. A kezdeti porlasztás befejeztével, mely a felület tisztítását szolgálja, a felgyorsult nitrogénionok hevítik a munkadarabot, egészen a nitridálási hőmérsékletig, melyet a feszültség szabályozásával érnek el. Ezt követően megkezdődik a nitrogénionok diffúziója az anyag belseje felé, valamint a nitridképződés [5-8]. A plazmanitridálási eljáráson belül három eljárásváltozatot különböztethetünk meg: egyenáramú plazmanitridálás (DCPN - direct current plasma nitriding), aktív ernyős plazmanitridálás (ASPN - active screen plasma nitriding) és aktív ernyős, előfeszítéses plazmanitridálás (ASBPN - active screen biased plasma nitriding). Az ASPN-eljárást a hagyományos plazmanitridálás technológiai hibáinak elkerülése érdekében (üregeskatód-hatás, sarokhatás) fejlesztették ki [9-11].

Az aktív ernyős plazmanitridálásnál a plazma nem közvetlenül a munkadarabon képződik, hanem a körülötte elhelyezett, ún. aktív ernyőn. Ebből adódóan az ionizált atomok és a hozzájuk tartozó pozitív töltésű ionok először az aktív ernyőt bombázzák. Az itt leválasztott vasionok a plazmatérben a nitrogénionokkal ütközve vas-nitridet alkotnak az aktív ernyő felülete mentén. A nitrid szemcsehalmazocskák között van olyan, amelyik megtapad az aktív ernyő felületén, azonban olyan is, amelyik az aktív ernyő perforáltságából adódóan keresztülrepül rajta, és megtapad a kezelendő munkadarabon, amelyet az aktív ernyő hősugárzása, valamint a gázbeadás és a vákuumszivattyú által fenntartott folyamatos plazmaáramlás melegít [11-13].

Az aktív ernyőt a felületszerkezete, próbatesttől való távolsága, anyaga jellemzi a következőben azonban csak az anyagra vonatkozó hatásokra térek ki. Naeem [14] kísérletében ausztenites acélból készült ernyőt használt, majd a felületi anyagösszetételi elemzésből megállapították, hogy nikkel és króm található a kezelt minta felületén, ami az aktív ernyő ionbombázásából eredő lerakódásnak köszönhető. Yazdani és társai [15] alumínium próbatestet nitridáltak ötvözetlen acél aktív ernyővel $550{ }^{\circ} \mathrm{C}$-on, $75 \% \mathrm{~N}_{2}+25 \% \mathrm{H}_{2}$ gázkeverékkel, különböző ideig. A próbatesteken $\mathrm{Fe}_{3} \mathrm{~N}$-réteg alakult ki, amely a próbatest köré elhelyezett ernyőről leváló vasból és a vele egyesülő nitrogénből származik.

Nemcsak a fémes anyagcsoport plazmanitridálására fordítanak figyelmet a kutatók, hanem a polimerekére is. Polipropilént nitridáltak 5-15 perc között, vizsgálva, hogy a polipropilén felületi adhéziós tulajdonsága milyen mértékben változik. Megfigyelték, hogy ennyi idő után is Fe tapadt meg a felületen, ami mindenképpen az aktív ernyőről került oda [16].

Kutatásunk során ötvözetlen acél és titán alapanyagú, illetve nikkelbevonatú aktív ernyővel nitridáltunk titánt és nemesíthető acélt, arra keresve a választ, hogy az ernyő anyaga hogyan befolyásolja a nitridréteg kialakulását, továbbá milyen kapcsolatot létesít a próbatest anyagával.

\section{Kísérletek és mérési módszerek}

\subsection{Felhasznált anyagok}

A próbatestek 42CrMo4, illetve Ti-6Al-4V ELI anyagú, Ø20 mm rúdanyagból méretre darabolt korongok. A korongok magassága $6 \mathrm{~mm}$. A nemesíthető acél próbatest nemesített állapotban került a plazmanitridáló kemencébe. Mindegyik próbatestet különböző SiC szemcseméretű csiszolópapírral csiszoltuk, majd $3 \mu \mathrm{m}$ gyémántszuszpenzióval políroztuk. A nitridálás előtt etanolban, ultrahangos rezgetővel tisztítottuk.

Az aktív ernyőre vonatkozó anyagok és méretek az 1. táblázatban találhatók. A próbatestek mindegyik esetben az ernyő közepén helyezkedtek el. Az ernyők perforálása lézersugaras vágással készült. A nikkelbevonatot galvanizálással vittük fel, $70 \mu \mathrm{m}$-es vastagságban.

1. táblázat. Az aktív ernyő felületének anyaga és a perforáltsági méretek

\begin{tabular}{|c|c|c|}
\hline Anyag & $\begin{array}{c}\text { Átmérő } \\
\text { (mm) }\end{array}$ & $\begin{array}{c}\text { Lyukátmérő } \\
(\mathbf{m m})\end{array}$ \\
\hline DC01 & 100 & 5 \\
\hline Titán 1 & 100 & 18 \\
\hline Titán 2 & 55 & 6 \\
\hline Nikkel & 100 & 5 \\
\hline
\end{tabular}

\subsection{Nitridálási körülmények}

A plazmanitridálási kísérleteket saját kísérleti berendezésünkben végeztük el. Az ötvözetlen acél és titán ernyőkkel készült próbatesteket $490{ }^{\circ} \mathrm{C}$-on, 4 órán keresztül, $75 \% \mathrm{~N}_{2}+25 \% \mathrm{H}_{2}$ gázkeverékkel nitridáltuk. A nikkelbevonatos próbatesteket $510^{\circ} \mathrm{C}$-on, szintén 4 órán keresztül, $75 \% \mathrm{~N}_{2}+25 \% \mathrm{H}_{2}$ gázkeverékkel kezeltük. 


\subsection{Vizsgálati módszerek}

A próbatestek felületéről nitridálás után sztereomikroszkópos képek készültek Olympus SZX16 mikroszkóppal. Keménységet Buehler IndentaMet 1105 típusú mikro-keménységmérővel mértünk. Az EDS-mérésekhez Zeiss EVO MA10 elektronmikroszkópot és EDAX Z2 detektort, az XPS-mérésekhez Phoibos 100 MCD-5 detektort használtunk.

\section{Plazmanitridálási kísérletek}

A kísérleteket először titán alapanyagon végeztük el, a titán korrózióállóságának javítása céljából, azonban megfigyeltük, hogy az aktív ernyőről leváló részecskék megtapadnak a felületen. Ezt követően kezdtük el vizsgálni az aktív ernyő hatását acél alapanyagon.

\subsection{Titán alapanyagon végzett plazmanitri- dálás különböző anyagú aktív ernyőkkel}

A nitridálás előtt és után tömegmérést végeztünk a próbatesten, melynek eredménye a 2 . táblázatban látható.

2. táblázat. Különböző aktív ernyőkkel nitridált titán próbatestek tömegmérési eredménye

\begin{tabular}{|l|c|c|c|}
\hline \multicolumn{1}{|c|}{ Minta jele } & $\mathbf{m}_{\text {kezd. }} \mathbf{( g )}$ & $\mathbf{m}_{\text {bef. }} \mathbf{( g )}$ & $\mathbf{\Delta} \mathbf{m}(\mathbf{g})$ \\
\hline Acélernyővel & 8,4130 & 8,4146 & 0,0016 \\
\hline Titánernyővel & 8,3364 & 8,3365 & 0,0001 \\
\hline
\end{tabular}

Megfigyelhető, hogy titánernyővel a próbatesten szinte nem következett be tömegnövekedés, míg az acélernyő esetén a nitridált minta tömege nagyobb.

Közvetlenül a nitridálás után a felületről készült képek az 1. ábrán láthatók.

Az 1. ábrán megfigyelhető, hogy az acélernyővel készült próbatest felülete matt maradt, míg a titánernyővel készültén meglátszanak a felület-előkészítés nyomai, valamint a fényt különbözőképpen töri meg a felület optikailag aktív rétege. Egyértelműen látszik, hogy a TiN-re jellemző aranysárga szín [17] nem alakult ki, ami arra utal, hogy ilyen típusú nitrid nem alakult ki a felületen.

A titán próbatest alapkeménysége 332 HV0,01 \pm 25 . Acélhálóval a próbatest keménysége 661 HV0,01 \pm 32 , ami az alapkeménység duplája, míg titánernyős nitridálás után a keménysége csak 436 × 14 HV0,01-re változott. A titán nitridei nitridálás után akár 1400 HV keménységet is elérhetnek [18]. Vagyis ezek alapján vagy nem alakult ki vegyületi réteg, vagy annyira kis vastagságú réteg alakult ki, hogy a keménységmérés során a gyé- mánt mérőcsúcs átnyomódott a teljes rétegen.

A próbatestek keresztmetszetéről készült képek a 2. ábrán láthatók.

A fémmikroszkópos felvételeken látható, hogy nitridréteg nem alakult ki a felületen. A minták szövetszerkezete különböző a felülethez közel és a minta közepén.

A keresztmetszeten végzett mikrokeménységmérésből kiderült, hogy a keménység 0,1 mm-en keresztül csökken le az alapkeménységre, mely az előző képekkel együtt azt bizonyítja, hogy a nitrogén bediffundált az anyagba.

Az EDS-analízissel megmértük a felület összetételét, melynek eredménye a 3. táblázatban látható.

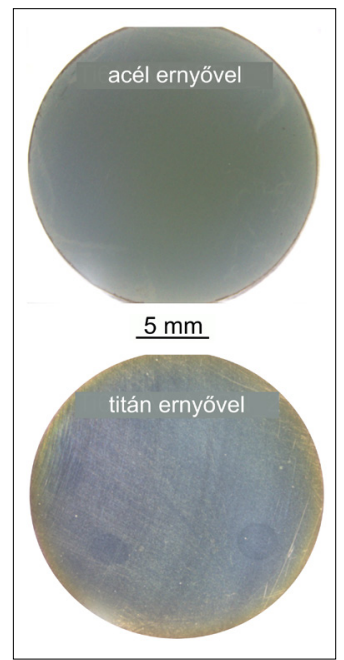

1. ábra. Különböző ernyővel nitridált titán próbatestek felületéről készült sztereomikroszkópos képek

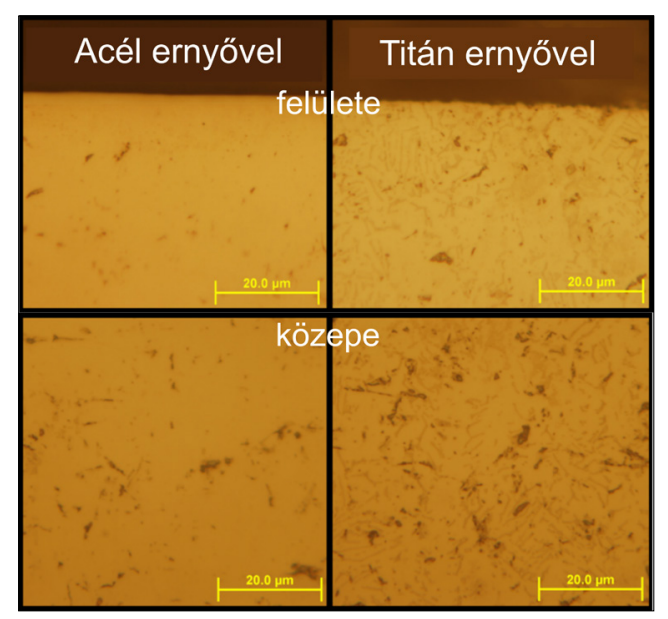

2. ábra. Különböző ernyőkkel nitridált titán próbatestek keresztmetszetéről készült optikai mikroszkópos képek 
3. táblázat. Különböző aktív ernyőkkel nitridált titán próbatestek EDS-analízissel mért felületianyagösszetétele

\begin{tabular}{|c|c|c|c|}
\hline $\begin{array}{c}\text { Elem } \\
\text { (\%) }\end{array}$ & Alapanyag & $\begin{array}{c}\text { Acél- } \\
\text { ernyővel }\end{array}$ & $\begin{array}{c}\text { Titán- } \\
\text { ernyővel }\end{array}$ \\
\hline $\mathrm{Ti}$ & 83,18 & 11,19 & 85,21 \\
\hline $\mathrm{Al}$ & 6,10 & 0,18 & 6,72 \\
\hline $\mathrm{V}$ & 4,33 & 0,91 & 3,77 \\
\hline $\mathrm{O}$ & 6,15 & 7,34 & 1,14 \\
\hline $\mathrm{Si}$ & 0,24 & - & - \\
\hline $\mathrm{N}$ & - & 7,40 & 3,16 \\
\hline $\mathrm{Fe}$ & - & 72,98 & - \\
\hline
\end{tabular}

Jól megfigyelhető, hogy acélernyővel a felület Ti-tartalma jelentősen lecsökkent az alapanyaghoz képest, a vas pedig nagy mennyiségben megjelent. A titánernyővel készült próbatesten a titán mennyisége növekedett, de a további értékek nem változtak jelentősen. Mindkét esetben megjelent a nitrogén. Ezek azt bizonyítják, hogy az ernyőről leváló részecskék megtapadnak a felületen, sőt képesek befedni a minta felületét.

\subsection{Nemesíthető acélon végzett plazmanitri- dálás titán anyagú aktív ernyővel}

Mivel a korábbi kísérletek során TiN-et nem tudtunk létrehozni a felületen, de az ernyőről levált részecskék megtapadtak a felületen, ezért kisebb átmérőjü aktív ernyőre és 42CrMo4 összetételü acélra váltottunk. A próbatestet ASPN_Ti-nek jelöltük.

A tömegmérésből származó eredményeket a 4. táblázat mutatja.

4. táblázat. Titán aktív ernyővel nitridált acél próbatestek tömegmérési eredménye

\begin{tabular}{|c|c|c|c|}
\hline Minta jele & $\mathbf{m}_{\text {kezd. }} \mathbf{( g )}$ & $\mathbf{m}_{\text {bef. }} \mathbf{( g )}$ & $\Delta \mathbf{m} \mathbf{( g )}$ \\
\hline ASPN_Ti & 12,5257 & 12,5267 & 0,0010 \\
\hline
\end{tabular}

Tömegnövekedés itt is, ahogyan a korábbi méréseknél is, tapasztalható, azonban ebben az esetben keménységnövekedés nem történt, a próbatest nitridálás utáni keménysége az alapkeménység szórásán belül maradt, azaz $320 \pm 20$ HV0,01. A felületen szintén nem alakult ki vegyületi réteg sem.

A nitridálás után a felületen különböző színárnyalatokat vettünk észre, ami a 3. ábrán látható. Ezek között a próbatest szélén az arany szín is megjelent, ezért az EDS-elemzés során a próbatest különböző pontjait vizsgáltuk. A mérési eredményeket az 5. táblázat mutatja.
5. táblázat. Titán aktív ernyővel nitridált acél próbatestek EDS-analízissel mért elemösszetétele

\begin{tabular}{|c|c|c|c|}
\hline $\begin{array}{c}\text { Elem } \\
(\%)\end{array}$ & Alapanyag & $\begin{array}{c}\text { ASPN_Ti } \\
\text { közepe }\end{array}$ & $\begin{array}{c}\text { ASPN_Ti } \\
\text { széle }\end{array}$ \\
\hline $\mathrm{N}$ & - & 7,46 & 4,86 \\
\hline $\mathrm{O}$ & - & 5,17 & 3,51 \\
\hline $\mathrm{Al}$ & - & 0,17 & - \\
\hline $\mathrm{Si}$ & 0,28 & 0,24 & - \\
\hline $\mathrm{Ti}$ & - & 5,98 & 3,37 \\
\hline $\mathrm{Cr}$ & 1,41 & 1,18 & 1,21 \\
\hline $\mathrm{Fe}$ & 99,4 & 79,79 & 87,05 \\
\hline $\mathrm{Mo}$ & 0,12 & - & - \\
\hline $\mathrm{Mn}$ & 0,74 & - & - \\
\hline
\end{tabular}

Megfigyelhető, hogy a próbatestre az ernyőből szintén rakódott le a felületre titán, azonban a szélén várt TiN-réteg biztosan nem alakult ki, hiszen a vastartalom ebben a pontban nagyobb, mint a közepén, továbbá a nitrogén mennyisége is csökkent ahhoz képest. A pontosabb meghatározáshoz XPS-analízist alkalmaztunk [19, 20], melynek eredményei a 6. táblázatban láthatók.

A felületen kialakult réteg teljesen lefedi az alapanyagot, mivel a spektrumokon nem látszik vas, króm vagy molibdén. A kialakult rétegben van titán és nitrogén is, azonban nincsenek kötésben. A próbatest eltérő színei titán-oxid kialakulására utalhatnak, azonban a mérések során (bár a kialakult kötések közelebb állnak a $\mathrm{TiO}_{2}$-höz, mint a TiN-hez) nem jelenthető ki teljes bizonyossággal, hogy a felületet csupán egy titán-oxid-réteg borítja. A legvalószínűbb, hogy a felületen egy $\operatorname{TiN}_{\mathrm{x}} \mathrm{O}_{\mathrm{y}}$-réteg keletkezik, amelynek vastagsága és összetétele a hely függvényében változhat.

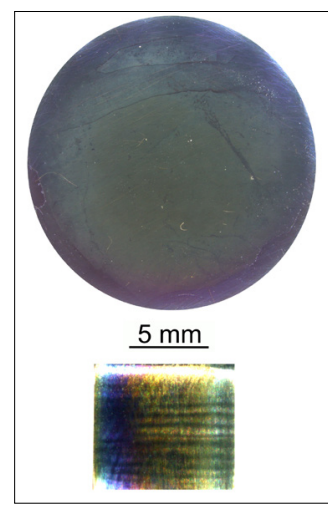

3. ábra. Titánernyővel nitridált, 42CrMo4 acél próbatest sztereomikroszkópos képe. Az alsó képen láthatók a nitridálás során kialakult színátmenetek 
6. táblázat. Titán aktív ernyővel nitridált acél próbatestek XPS-analízissel mért elemösszetétele a minta közepén

\begin{tabular}{|c|c|}
\hline Elem & Mennyiség (\%) \\
\hline C1s & 74,88 \\
\hline N1s & 2,22 \\
\hline O1s & 16,06 \\
\hline Ti2p & 4,24 \\
\hline Ca2p & 1,53 \\
\hline Mn2p & 0,36 \\
\hline Si2p & 0,38 \\
\hline Na1s & 0,07 \\
\hline
\end{tabular}

\subsection{Nemesíthető acélon végzett plazmanitri- dálás nikkelbevonatos aktív ernyővel}

Az aktív ernyő alapanyaga ötvözetlen acél, melyre galvanizálással $70 \mu \mathrm{m}$ vastagságú nikkelréteget vittünk fel.

A nitridálást követően a felület egyenletes, világosszürke színü lett (4. ábra), melyen némileg még látszottak a polírozás nyomai, így arra következtettünk, hogy vegyületi réteg ismét nem keletkezett a próbatesten.

$\mathrm{Az}$ optikai mikroszkópos képen (5. ábra) látható, hogy vegyületi réteg nem keletkezett, amit a keménység is igazol. Ennél a próbatestnél sem növekedett a próbatest keménysége, szóráson belül maradt, ami $420 \pm 45$ HV0,01.

További vizsgálatokat végeztünk el XPS-analízissel, melyhez először leporlasztottuk a felület felső 100 nm-ét, majd ebben a mélységben megvizsgáltuk az anyagösszetételt. Az erre szolgáló grafikon a 6. ábrán látható.

Ahogy a 6. ábrából kiolvasható, a nitrogén nem létesített kötést a vassal, tehát nincs vas-nitrid - az előzetes feltevéseket igazolva -, valóban nem keletkezett a felületen. A nitrogén 84\%-ban molekuláris $\left(\mathrm{N}_{2}\right)$ formában van jelen a vizsgált rétegben, ami annak porózusságával magyarázható. Kismértékben (16\%) karbo-nitrid is megjelent, amelynek felületkeményítő hatása nem volt kimutatható a keménységmérés során.

\section{4. Összefoglalás}

Az aktív ernyő felületének anyaga az alábbi módokon befolyásolja a nitridált munkadarab felületi tulajdonságait aktív ernyős plazmanitridálás során:

- nincs keménységnövelő hatás;

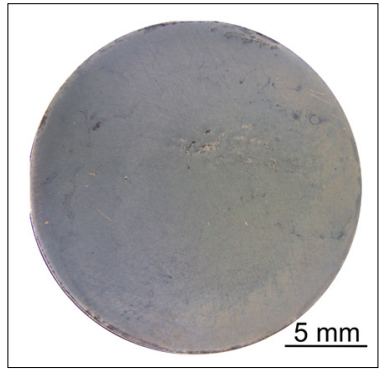

4. ábra. Nikkelbevonatos ernyővel nitridált 42CrMo4 acél próbatest sztereomikroszkópos képe

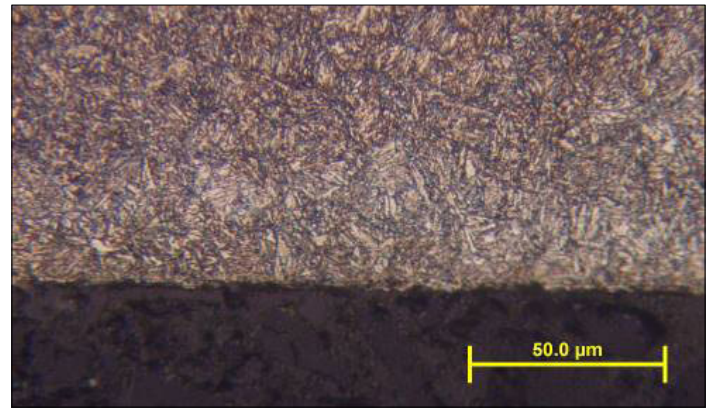

5. ábra. Nikkelbevonatos ernyővel nitridált 42CrMo4 acél próbatest szövetképe

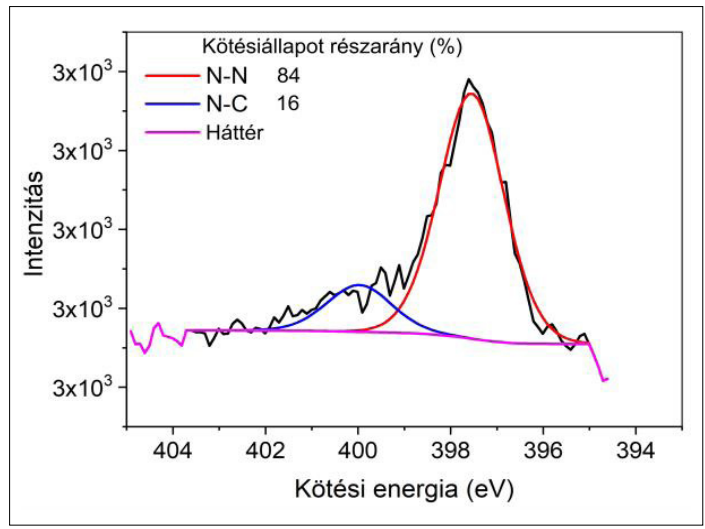

6. ábra. Nikkelbevonatos ernyővel nitridált 42CrMo4 összetételü próbatest XPS-mérési grafikonja

- nem alakult ki vegyületi réteg a felületen, tehát nem képződik vas-nitrid;

- az aktív ernyőből származó részecskék lerakódnak a felületen.

Nikkelbevonatú aktív ernyő esetén, 75\% $\mathrm{N}_{2}+$ $25 \% \mathrm{H}_{2}$ gázkeverék használatával, $510{ }^{\circ} \mathrm{C}$-on, 4 órás aktív ernyős plazmanitridálással az ernyő felületéből származó nikkel beötvöződik a felületbe több száz nm-es vastagságban, miközben vas-nitrid-fázisok nem alakulnak ki. Ez akár új felületötvözési eljárásnak is tekinthető. 


\section{Köszönetnyilvánítás}

A szerzők köszönettel tartoznak Takáts Viktornak, a debreceni Atommag Kutató Intézet munkatársának és Dobos Gábornak, a BME Atomfizika Tanszék munkatársának az XPS-mérések elvégzéséért.

\section{Szakirodalmi hivatkozások}

[1] Yaghmaee M.S, Kaptay G.: The Solubility of Nitrogen and Nitrides in Ternary Liquid Iron Alloys. The Limits of the 'Solubility Product' Concept. Materials Science Forum, 414-415. (2003) 491-496.

[2] Kolozsváry Z.: Nitriding structure and properties of nitrided layar. ASM Handbook, Volume 4D, Heat Treating of Irons and Steels (2014) 88-96. https://doi.org/10.31399/asm.hb.v04d.a0005986

[3] Szilágyiné B. A.: Trends of nitriding processes. Production Processes and Systems, 6. (2013) 57-69.

[4] Aizawa T., Wasa K.: Low temperature plasma nitriding of inner surfaces in stainless steel mini-/micro-pipes and nozzles, Micromachines, 8. (2017) 1-9. https://doi.org/10.3390/mi8050157

[5] Szilágyiné B. A., Kocsisné B. M.: Comparison of gas and plasma nitrocarburised surface layer of $16 \mathrm{CrMo5}$ steel. Proceedings - European Conference on Heat Treatment and 21 ${ }^{\text {st }}$ IFHTSE Congress (2014) 551-558.

[6] Börner K., Burlacov I., Spies H., Biermann H., Hamann S., Röpcke J.: Investigations on the active screen plasma nitriding process. In: $13^{\text {th }}$ International Conference on Plasma Surface Engineering (2012) 96-99.

[7] Middendorf C., Mader W.: Growth and microstructure of iron nitride layers and pore formation in $\varepsilon$-Fe3N. Zeitschrift für Metallkunde/Materials Research and Advanced Techniques, 94. (2003) https://doi.org/10.3139/146.030333

[8] Kenéz L., Kutasi N., Filep E., Jakab-Farkas L., Ferencz L.: Anodic plasma nitriding in hollow cathode (HCAPN). HTM - Journal of Heat Treatment and Materials, 73. (2018) 96-105. https://doi.org/10.3139/105.110344.

[9] Li Y., Zhang S., He Y., Zhang L., Wang L.: Characteristics of the nitrided layer formed on AISI 304 austenitic stainless steel by high temperature nitriding assisted hollow cathode discharge. Materials and Design, 64. (2014) 527-534. https://doi.org/10.1016/j.matdes.2014.08.023.

[10] Sousa de R. R. M., Araújo de F. O., Costa da J. A. P., Dumelow T., Oliveira de R. S., Alves C.: Nitriding in cathodic cage of stainless steel AISI 316: Influence of sample position. Vacuum, 83. (2009) 1402-1405.

https://doi.org/10.1016/j.vacuum.2009.04.054
[11] Salavat M. K., Soltanieh M., Niasari M. H.: Diffusion Layer Growth Mechanism in ASPN Method Using an Iron Cage for St52 Steel. In: Proceedings of the $2^{\text {nd }}$ World Congress on Mechanical, Chemical, and Material Engineering (MCM'16) (2016) 1-8. https://doi.org/10.11159/mmme16.106

[12] Gallo C. S., Dong H.: On the fundamental mechanisms of active screen plasma nitriding. Vacuum, 84. (2009) 321-325.

https://doi.org/10.1016/j.vacuum.2009.07.002

[13] Zaho C., Li C. X., Dong H., Bell T.: Study on the active screen plasma nitriding and its nitriding mechanism. Surface and Coatings Technology, 201. (2006) 2320-2325.

https://doi.org/10.1016/j.surfcoat.2006.03.045

[14] Naeem M., Sha M., Zaka-ul-islam M., Ashiq A., Díaz-Gullién J. C., Shahzad M., Zakaullah M.: Enhanced surface properties of plain carbon steel using plasma nitriding with austenitic steel cathodic cage. Materials and Design, 108. (2016) 745-753. https://doi.org/10.1016/j.matdes.2016.07.044

[15] Yazdani A., Soltanieh M., Aghajani H.: Active screen plasma nitriding of Al using an iron cage: Characterization and evaluation. Vacuum, 122. (2015) 127-134.

https://doi.org/10.1016/j.vacuum.2015.09.018

[16] Kauling A. P., Soares G. V., Figueroa C. A., Oliverira de R. V. B., Baumvol I. J. R., Giacomelli C., Miotti L.: Polypropylene surface modification by active screen plasma nitriding. Materials Science and Engineering, C, 29. (2009) 363-366.

https://doi.org/10.1016/j.msec.2008.07.002

[17] Kamat A. M., Copley S. M., Todd J. A.: Effect of processing parameters on microstructure during laser-sustained plasma (LSP) nitriding of commercially-pure titanium. Acta Materiala, 107. (2016) 72-82.

https://doi.org/10.1016/j.actamat.2016.01.051

[18] Nishimoto A., Nii H., Narita, Akamatsu K.: Simultaneous duplex process of TiN coating and nitriding by active screen plasma nitriding. Surface and Coatings Technology, 228. (2013) 558-562. https://doi.org/10.1016/j.surfcoat.2012.04.021

[19] Kovách G., Csorbai H., Dobos G., Karacs A., Pető G.: Formation and characterization of electric contacts on CVD diamond films prepared by ion implantation, Materials Science Forum, 473-474. (2005) 123-128.

https://doi.org/10.4028/www.scientific.net/ MSF.473-474.123

[20] Takáts V., Csík A., Hakl J., Vad K.: Diffusion induced atomic islands on the surface of $\mathrm{Ni} / \mathrm{Cu} \mathrm{na}$ nolayers. Applied Surface Science, 440. (2018) 275-281. https://doi.org/10.1016/j.apsusc.2018.01.087 